\title{
‡USGS
}

science for a changing world

Prepared in cooperation with the University of Waterloo, Canada

Integrated Analysis of Flow, Temperature, and SpecificConductance Logs and Depth-Dependent Water-Ouality Samples from Three Deep Wells in a Fractured-Sandstone Aquifer, Ventura County, California
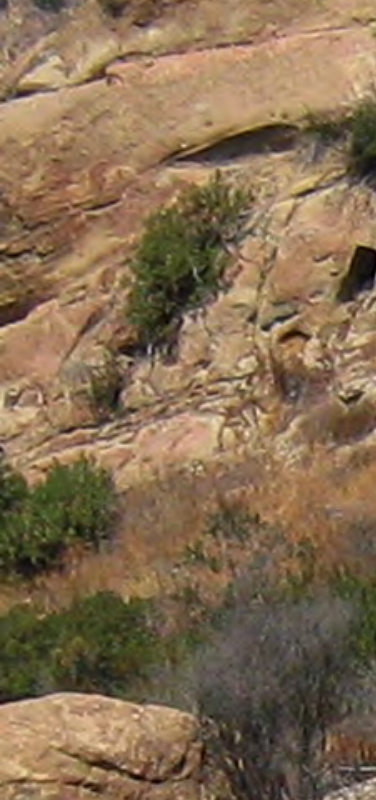
4ank?

c)

Open-File Report $2009=1023$
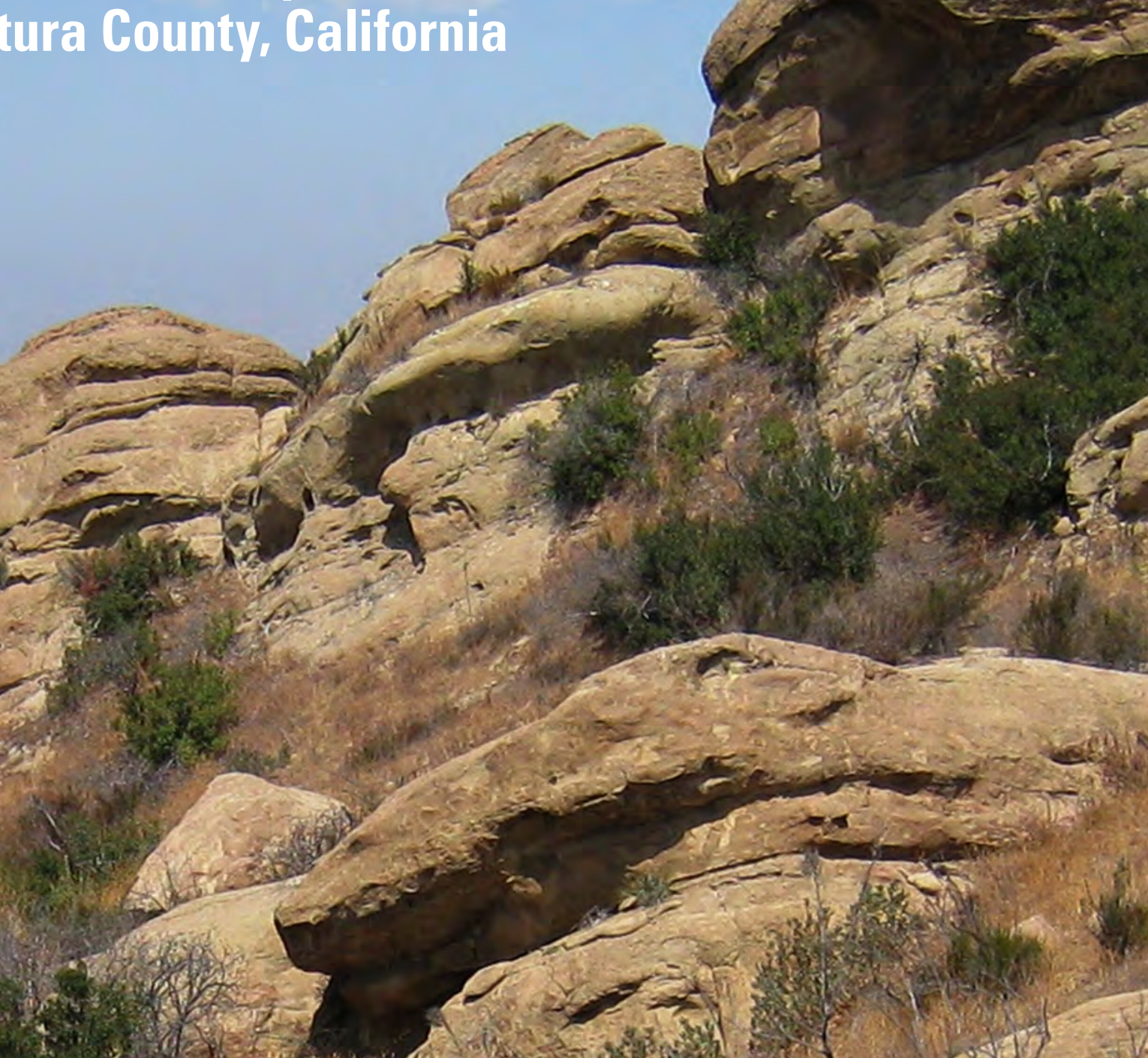
Cover. Outcrop of fractured sandstone at the Santa Susana Field Laboratory, Ventura County, California. Photograph courtesy of MWH Americas, Inc. 


\section{Integrated Analysis of Flow, Temperature, and Specific-Conductance Logs and Depth-Dependent Water-Quality Samples from Three Deep Wells in a Fractured- Sandstone Aquifer, Ventura County, California}

By John H. Williams and Kevin D. Knutson

Prepared in cooperation with the University of Waterloo, Canada

Open-File Report 2009-1023 


\title{
U.S. Department of the Interior \\ KEN SALAZAR, Secretary
}

\author{
U.S. Geological Survey \\ Suzette M. Kimball, Acting Director
}

U.S. Geological Survey, Reston, Virginia: 2009

For more information on the USGS - the Federal source for science about the Earth, its natural and living resources, natural hazards, and the environment, visit http://www.usgs.gov or call 1-888-ASK-USGS

For an overview of USGS information products, including maps, imagery, and publications, visit http://www.usgs.gov/pubprod

Any use of trade, product, or firm names is for descriptive purposes only and does not imply endorsement by the U.S. Government.

Although this report is in the public domain, permission must be secured from the individual copyright owners to reproduce any copyrighted materials contained within this report.

Suggested citation:

Williams, J.H., and Knutson, K.D., 2009, Integrated analysis of flow, temperature, and specific-conductance logs and depth-dependent water-quality samples from three deep wells in a fractured-sandstone aquifer, Ventura County, California: U.S. Geological Survey Open-File Report 2009-1023, 10 p., online only. 


\section{Contents}

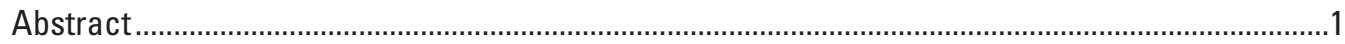

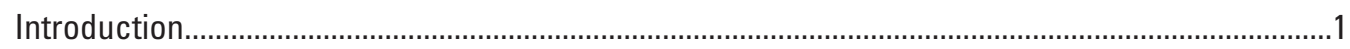

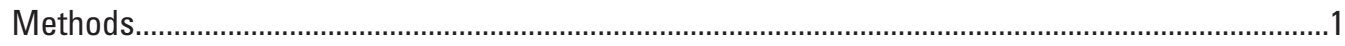

Integrated Analysis of Logs and Water-Quality Samples ..............................................................

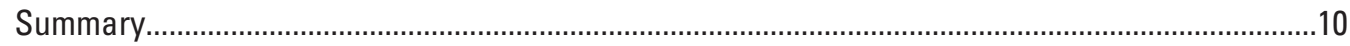

References Cited

\section{Figures}

1. Map showing location of Santa Susana Field Laboratory and abandoned water-supply wells, southern Ventura County, California....................................................2

2. Hydrographs showing depth to water level during ambient, pumping, and recovery conditions for abandoned water-supply well (A) WS-12, (B) WS-13, and (C) WS-14, Santa Susana Field Laboratory, Ventura County, California .....................5

3. Diagrams showing geophysical logs and water-quality-sampling results for abandoned water-supply well (A) WS-12, (B) WS-13, and (C) WS-14, Santa Susana Field Laboratory, Ventura County, California

\section{Tables}

1. Well-construction, water-level, and specific-capacity information for abandoned water-supply wells WS-12, 13, and 14, Santa Susana Field Laboratory, Ventura County, California.

\section{Conversion Factors and Datums}

\begin{tabular}{lcl}
\hline \multicolumn{1}{c}{ Multiply } & By & \multicolumn{1}{c}{ To obtain } \\
\hline inch (in.) & Length & \\
foot (ft) & 2.54 & centimeter $(\mathrm{cm})$ \\
\hline \multicolumn{3}{c}{ Flow rate } \\
\hline gallon per minute $(\mathrm{gal} / \mathrm{min})$ & 0.06309 & meter $(\mathrm{m})$ \\
\hline & Specific capacity & \\
\hline gallon per minute per foot $[(\mathrm{gal} / \mathrm{min}) / \mathrm{ft})]$ & 0.2070 & liter per second $(\mathrm{L} / \mathrm{s})$ \\
\hline
\end{tabular}


Temperature in degrees Celsius $\left({ }^{\circ} \mathrm{C}\right)$ may be converted to degrees Fahrenheit $\left({ }^{\circ} \mathrm{F}\right)$ as follows:

$$
{ }^{\circ} \mathrm{F}=\left(1.8 \times{ }^{\circ} \mathrm{C}\right)+32
$$

Vertical coordinate information is referenced to the National Geodetic Vertical Datum of 1929 (NGVD 29).

Horizontal coordinate information is referenced to the North American Datum of 1983 (NAD 83).

Specific conductance is given in microsiemens per centimeter at 25 degrees Celsius $\left(\mu \mathrm{S} / \mathrm{cm}\right.$ at $\left.25^{\circ} \mathrm{C}\right)$.

Concentrations of chemical constituents in water are given either in milligrams per liter (mg/L) or micrograms per liter $(\mu \mathrm{g} / \mathrm{L})$. 


\title{
Integrated Analysis of Flow, Temperature, and Specific- Conductance Logs and Depth-Dependent Water-Quality Samples from Three Deep Wells in a Fractured-Sandstone Aquifer, Ventura County, California
}

\author{
By John H. Williams and Kevin D. Knutson
}

\section{Abstract}

Analysis of flow, temperature, and specific-conductance logs and depth-dependent water-quality samples collected under ambient and pumped conditions provided a preliminary delineation of flow zones and water quality in three deep abandoned water-supply wells. The integrated analysis was completed as part of the characterization of a fractured-sandstone aquifer in the mountainous setting of the Santa Susana Field Laboratory in southern Ventura County, California.

In the deepest well, which was 1,768 feet deep and had the highest specific capacity (120 gallons per minute per foot), flow zones were detected at 380 feet (base of casing) and at 440, 595, and 770 feet in the open hole. Under ambient conditions, measured flow was downward from the 380- and 440-foot zones to the 595- and 770-foot zones. Under pumped conditions, most of flow was contributed by the 595 -foot zone. Flow from the 380- and 440-foot zones appeared to have lower specific conductance and higher trichloroethylene concentrations than that from the 595-foot zone.

In the shallowest well, which was reportedly 940 feet deep but only logged to 915 feet due to blockage, flow zones were detected behind the perforated casing and at 867 feet in the open hole. Under ambient conditions, downward and upward flows appeared to exit at a zone behind the perforated casing at 708 feet. Most of the pumped flow was contributed from zones behind the perforated casing between 565 and 708 feet. Pumped flow also was contributed by zones at 867 feet and below the logged depth. Volatile organic compounds were not detected in the ambient and pumped flows.

In the third well, which was 1,272 feet deep and had the lowest specific capacity (3.6 gallons per minute per foot), flow zones were detected in the open hole above and just below the water level near 337 feet and at 615, 785, 995, and 1,070 feet. Under ambient conditions, measured flow in well was downward from the shallowmost zones to the 995 -foot zone.
Fracture zones at 615, 785, and 995 feet each contributed about one-third of the pumped flow measured below the pump. Volatile organic compounds were not detected in the ambient and pumped flows.

\section{Introduction}

Analysis of flow, temperature, specific-conductance logs, and depth-dependent water-quality samples provides an efficient means for the preliminary delineation of flow zones and water quality in multiple-zone wells. The purpose of this study was to demonstrate the application of this integrated analysis as part of the geohydrologic characterization of deep wells completed in a fractured-sandstone aquifer.

This study was done in cooperation with the University of Waterloo, who is providing technical assistance to the Boeing Company in their ongoing investigation of volatile organic compound (VOC) contamination in the fractured sandstone underlying the mountainous setting of the Santa Susana Field Laboratory, southern Ventura County, California (fig. 1). The geophysical logging and water-quality sampling were completed in three deep abandoned water-supply wells during November 2005. This report describes the methods used in the study and presents the geophysical log and waterquality data and their preliminary analysis.

\section{Methods}

Geophysical logs and depth-dependent water-quality samples were collected from wells WS-12, WS-13, and WS-14. The geophysical logs included temperature, specific conductance, flow, caliper, and gamma. The caliper logs of wells WS-12 and WS-14 were previously collected by Schlumberger Water Services. Flow, temperature, specificconductance logging, and depth-dependent water-quality sampling were completed under ambient and pumped 


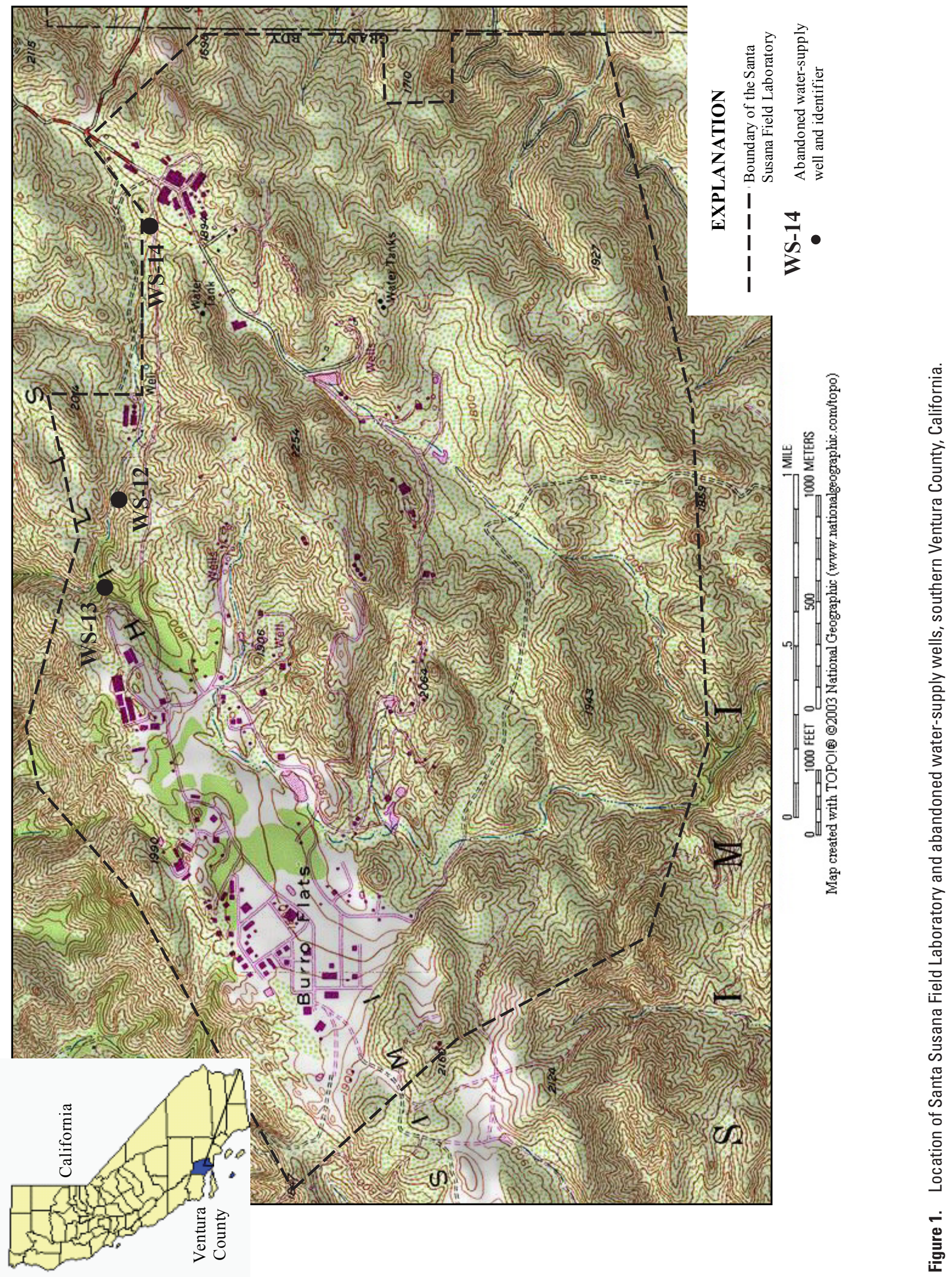


conditions in each well. Pump setup and containment of the pumped discharge, monitoring of discharge rates and water levels, and water-quality sampling and analyses were coordinated by MWH Americas, Inc., site consultant to the Boeing Company. The logs and all other data are referenced to depth below top of well casing.

The geophysical logs and depth-dependent water-quality samples are briefly described below. Additional information on geophysical logs is presented in Keys (1990).

Temperature logs recorded the temperature of the water in the wellbores. Temperature logs were collected under ambient and pumped conditions. Temperature gradients less than the geothermal gradient in the surrounding rocks indicate intervals with vertical wellbore flow. As wellbore flow decreases, the temperature gradient of the wellbore water approaches the geothermal gradient. Downflow is characterized by wellbore water cooler than that in equilibrium with the geothermal gradient. Conversely, upflow is characterized by wellbore water warmer than that in equilibrium with the geothermal gradient. The geothermal gradient in the study area is not known. The generally accepted range for the geothermal gradient in southern California is 0.6 to $1.2^{\circ} \mathrm{C}$ per $100 \mathrm{ft}$. However, the geothermal gradient in this mountainous setting would be expected to be less than typical because of the dissipation of heat on the flanks of the topographic high (Peeter Pehme, University of Waterloo, written commun., 2008). Temperature logs were used with the specific-conductance and flow logs to identify flow zones and intervals of flow under ambient and pumped conditions.

Specific-conductance logs recorded the electrical conductivity of the water in the wellbores. The specific conductance of the water is related to the dissolved-solids concentration. Ambient and pumped logs of fluid resistivity, which is inversely related to specific conductance, were collected and converted to specific conductance at $25^{\circ} \mathrm{C}$ using the temperature logs. Specific-conductance logs were used with the temperature and flow logs to identify flow zones under ambient and pumped conditions and approximate the dissolved-solids concentration.

Flow logs recorded the direction and rate of vertical flow in the wellbores. An electromagnetic (EM) flowmeter (Young and Pearson, 1995) was used to measure vertical flow in this study. The flow of water (an electrical conductor) through an induced magnetic field generates a voltage gradient that, according to Faraday's Law, is proportional to its velocity. Stationary flow measurements were made under ambient conditions, and both trolling and stationary measurements were made under pumped conditions. The flow logs were used with the temperature and specific-conductance logs to identify major flow zones and the direction and rate of flow between flow zones under ambient and pumped conditions.

The measurement drift of the EM-flowmeter results in an approximate tool resolution of plus or minus $0.02 \mathrm{gal} / \mathrm{min}$ when it is configured with a fully fitted flow restrictor. The large diameters of the wells in this study necessitated the use of an underfit diverter. The flowmeter was configured with a 6.5-in.-diameter diverter. A bypass factor, or multiplication factor used to convert the flow rates measured using an underfit diverter to estimated flow rates (Paillet, 2004), were determined for each well. A bypass factor of 150 was estimated for well WS-12 on the basis of a set of flow measurements with the flowmeter in a stationary position just below the pump and within the 14-in.-diameter casing while pumping at 35,55 , and $75 \mathrm{gal} / \mathrm{min}$. The tool response was linear over the range of flows tested. A bypass factor of 95 was estimated for well WS-13 on the basis of the flow measurement with the flowmeter in a stationary position just below the pump and within the 12-in.-diameter perforated casing while pumping at $99.5 \mathrm{gal} / \mathrm{min}$. this estimated bypass factor was based on the assumption that none of the pumped discharge was contributed from the perforated interval above the pump. A bypass factor of 115 was estimated for WS-14 on the basis of its open-hole diameter of $12.75 \mathrm{in}$., the estimated bypass factors for WS-12 and WS-13, and the ratios of the cross-sectional areas of the three wellbores. The estimated bypass factors would suggest that the lower measurement limit was on the order of several gallons per minute. However, the response of the tool with the underfit diverter in these large-diameter wells to low-rate flows was not quantitatively evaluated. The appropriate bypass factors were applied to each set of ambient and pumped flowmeter measurements. The trolling flowmeter logs were calibrated to the stationary flowmeter measurements to provide a continuous estimate of flow under pumped conditions.

Through a comparison with hydraulic testing by use of inflatable straddle packers in open wells in fractured bedrock, Paillet (1998) showed that the flow-log method consistently detected flow zones with transmissivity values having the same order of magnitude as the most permeable zone in the well. In addition, about half of the flow zones with transmissivity values an order of magnitude less than the most permeable zone were detected, and fewer than 20 percent of the zones with transmissivity values two orders of magnitude lower were detected. In the present study, given the rugosity of the wellbores and use of the underfit diverters, flow zones with transmissivity values less than the same order of magnitude as the most permeable zone in the well were not likely to be detected by the flow-log method.

Caliper logs recorded the diameter of the wells. Changes in diameter are related to drilling and well construction, caving of non-competent rocks, and fracture zones. Because flow velocity varies with well diameter for a given wellbore flow, caliper logs are critical for the collection and analysis of flow logs. Stationary flowmeter measurements were collected in competent intervals above and below potential fracture zones as identified on the caliper logs.

Gamma logs record the amount of gamma radiation emitted by the rocks surrounding the wells. Clay-bearing rocks commonly emit relatively high gamma radiation because they include weathering products of potassium feldspar and mica and tend to concentrate uranium and thorium by ion 
absorption and exchange. Naturally occurring sources of gamma radiation include potassium- 40 and daughter products of the uranium- and thorium-decay series. The vertical resolution of the gamma probe is 1 to $2 \mathrm{ft}$.

Depth-dependent water-quality samples provided for measurements of the quality of water in the wellbores at specific depths. Water samples were collected under ambient conditions and under pumped conditions at the same rates as collection of the flow logs. The sampler used in this study is a piston-driven device that is remotely controlled by a wireline to collect a small volume of water from the wellbore at a selected depth. The selection of the depths to sample was determined by analysis of the caliper, flowmeter, temperature, and specific-conductance logs. Depths were selected so that the water sampled was representative of the ambient or pumped flow from one or more identified flow zones (Williams and Conger, 1990). Additional samples were collected in the deeper intervals of wells WS-12 and WS-14, although the source(s) of this wellbore water was not determined from the geophysical logs. The water samples were analyzed for total dissolved solids, major anions and cations, and VOCs. The VOC analysis included trichloroethylene (TCE), cis-1,2-dichlorethene (cis-1,2-DCE), and trans-1,2-dichlorethene (trans-1,2-DCE).

\section{Integrated Analysis of Logs and Water-Quality Samples}

The geophysical logs and results of the depth-dependent water-quality sampling were analyzed along with the wellconstruction and specific-capacity test information for each of the three deep abandoned water-supply wells.

Well WS-12 was cased with 14-in.-diameter steel casing to a depth of $380 \mathrm{ft}$ and was completed as a 14-in.-diameter open hole to a depth of 1,768 ft (table 1). Altitude of the well was $1,705.98 \mathrm{ft}$ above NGVD 29. The well had an ambient water-level depth of $130.36 \mathrm{ft}$. The well was pumped at a rate of $75 \mathrm{gal} / \mathrm{min}$, which resulted in $0.64 \mathrm{ft}$ of drawdown after 150 minutes of pumping (fig. 2A). The specific capacity of the well was 120 (gal/min)/ft, which was the highest specific capacity of the three wells.

Under ambient conditions, measurable flow in well WS-12 was downward at a rate of several gallons per minute from near the base of casing at $380 \mathrm{ft}$ and from a fracture zone at $440 \mathrm{ft}$ (fig. 3A). This inflow had a specific conductance of less than $1,000 \mu \mathrm{S} / \mathrm{cm}$ at $25^{\circ} \mathrm{C}$ and total dissolved-solids concentration of $560 \mathrm{mg} / \mathrm{L}$. Concentrations of TCE and cis-1,2-DCE were 26 and $20 \mu \mathrm{g} / \mathrm{L}$, respectively, and trans-1,2-DCE was not detected. The flow log indicated that additional downward flow was contributed by the fracture zone at $595 \mathrm{ft}$, which is at a lithologic change indicated by the gamma log. However, the increase in the gradient of the temperature log from below the $595-\mathrm{ft}$ zone compared to that above is not consistent with this zone contributing additional

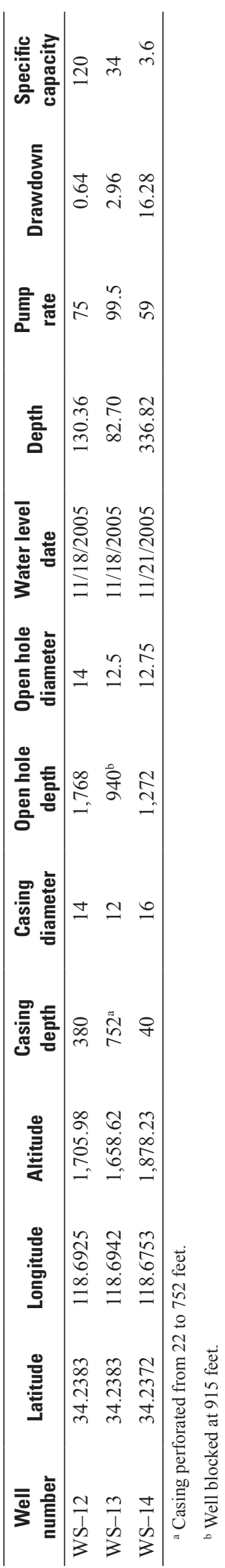



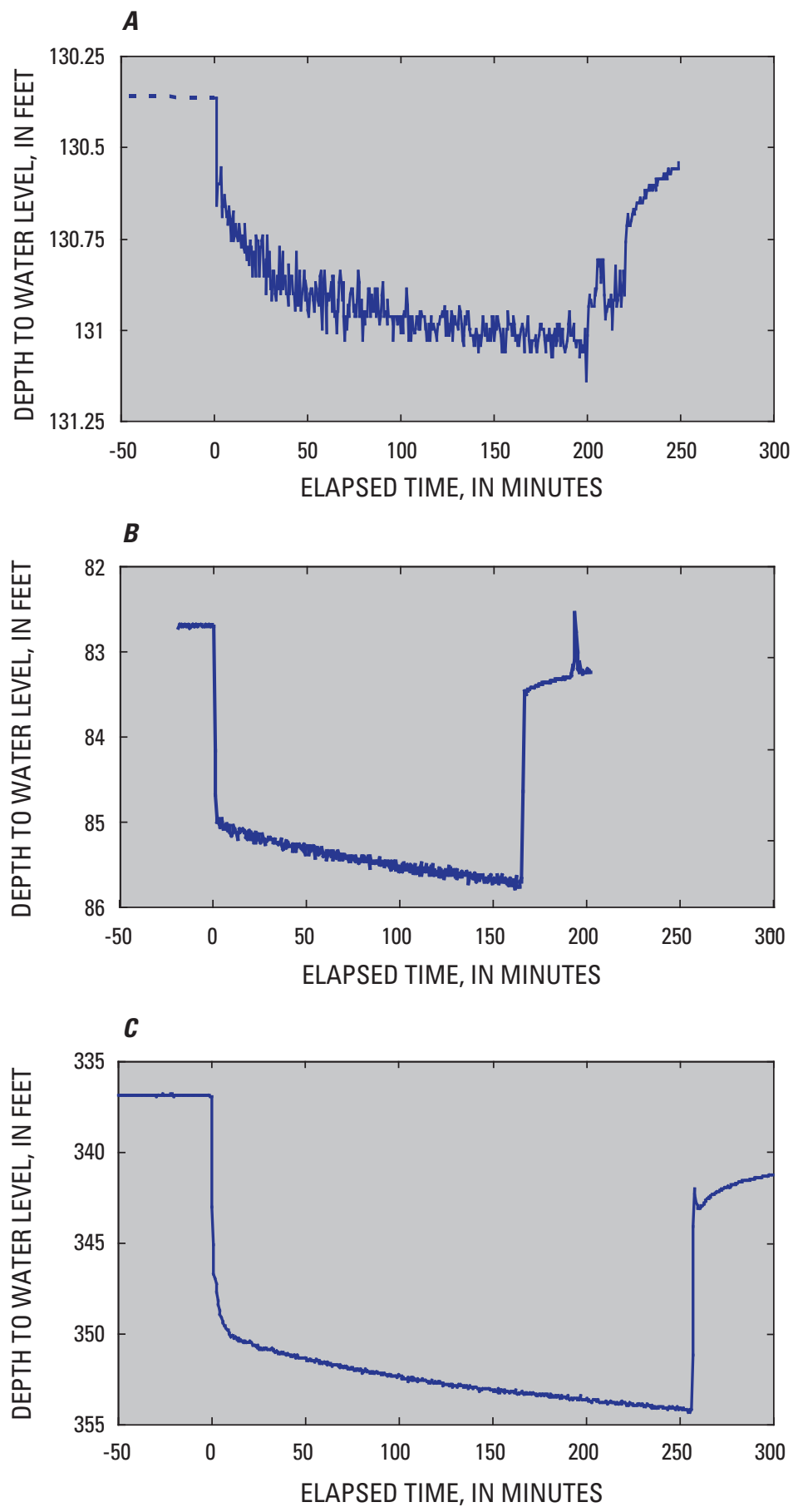

Figure 2. Depth to water level during ambient, pumping, and recovery conditions for abandoned water-supply well (A)WS-12, (B) WS-13, and (C) WS-14, Santa Susana Field Laboratory, Ventura County, California. 
$\boldsymbol{A}$

WS-12

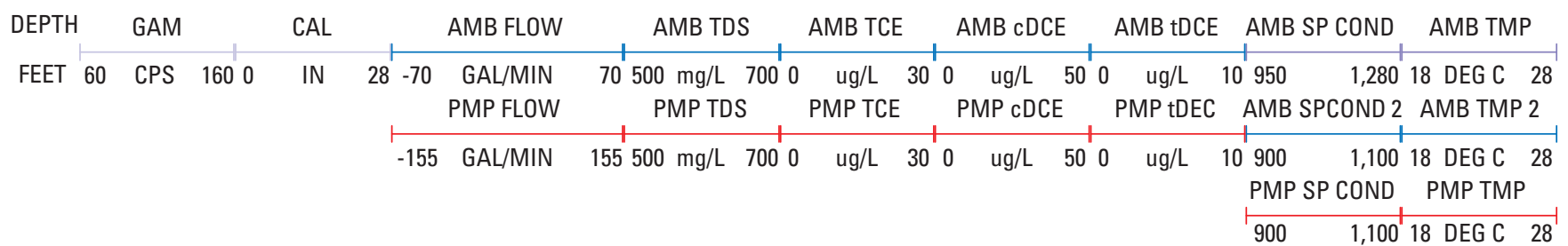

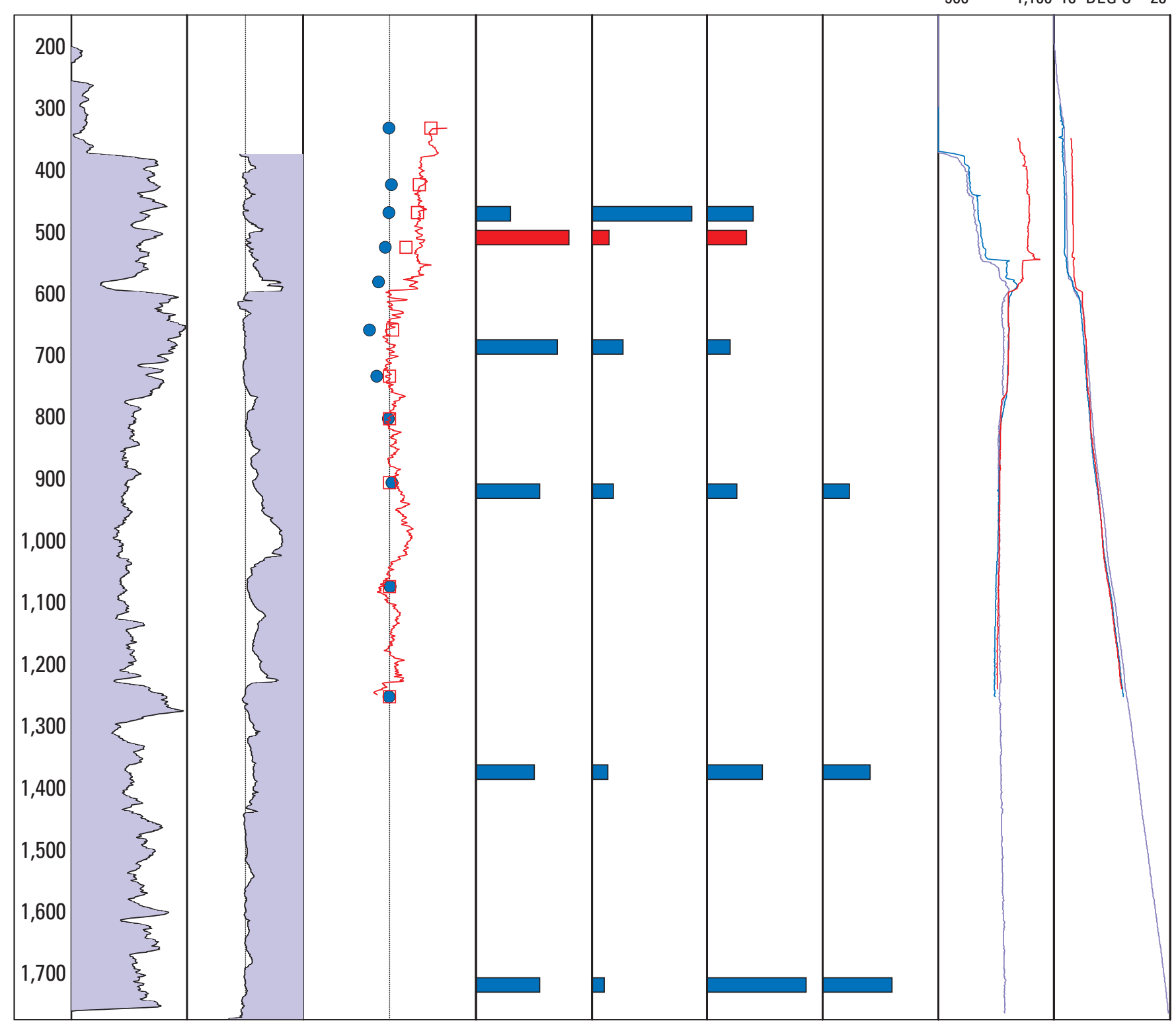

Figure 3. Geophysical logs and water-quality-sampling results for abandoned water-supply well (A)WS-12, (B) WS-13, and (C) WS-14, Santa Susana Field Laboratory, Ventura County, California. [DEPTH FEET (depth below top of casing, in feet); GAM CPS (gamma, in counts per second); CAL IN (caliper, in inches); AMB (ambient conditions); PMP (pumped conditions); FLOW GAL/MIN (ambient flow, in gallons per minute); TDS (total dissolved solids); SULF (dissolved sulfate), mg/L (milligrams

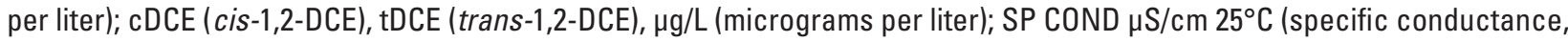
in microsiemens per centimeter at 25 degrees Celsius); and TMP DEG C (temperature, in degrees Celsius).] 
B

WS-13

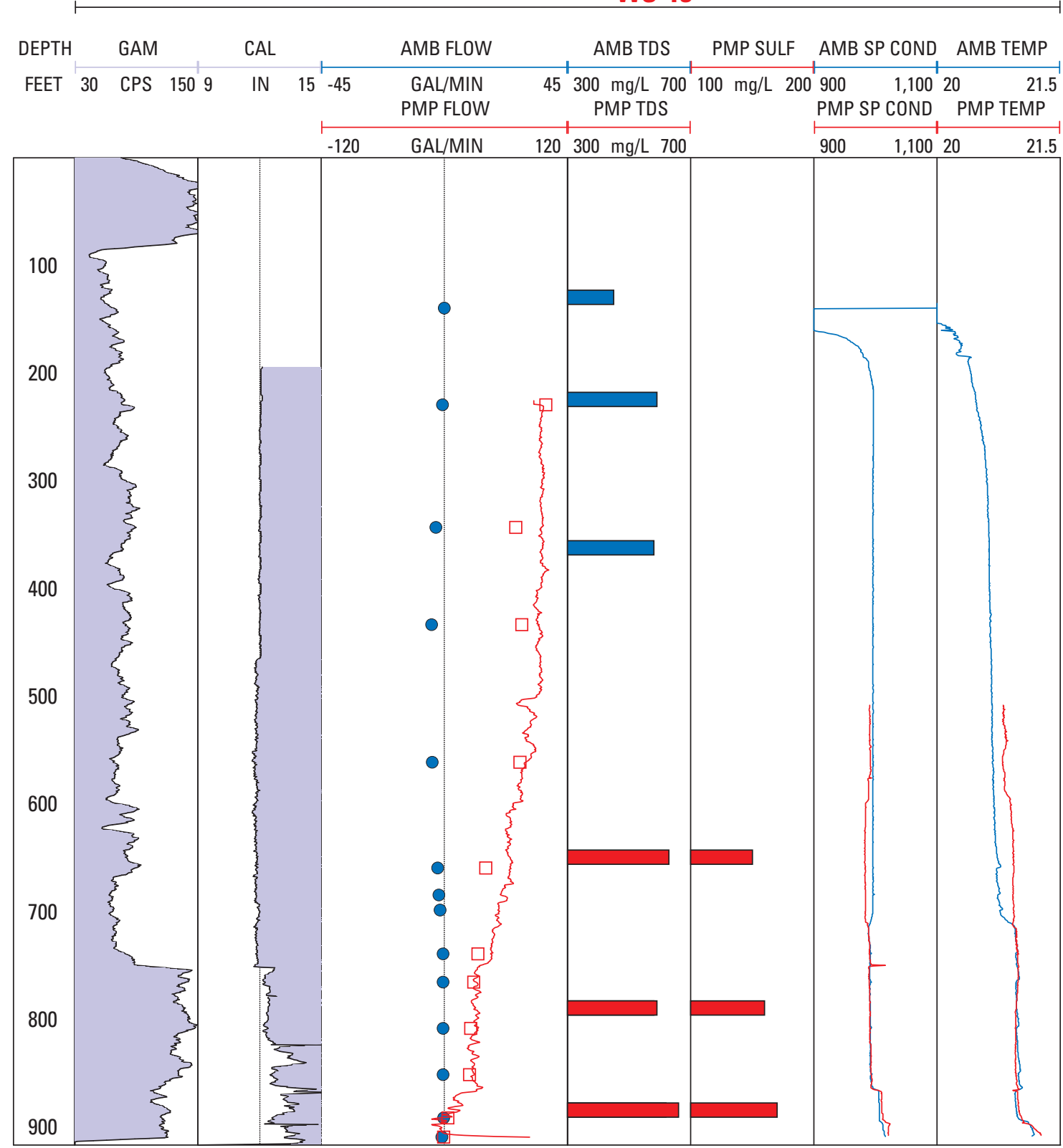

Figure 3. Geophysical logs and water-quality-sampling results for abandoned water-supply well (A)WS-12, $(B)$ WS-13, and (C) WS-14, Santa Susana Field Laboratory, Ventura County, California. [DEPTH FEET (depth below top of casing, in feet); GAM CPS (gamma, in counts per second); CAL IN (caliper, in inches); AMB (ambient conditions); PMP (pumped conditions); FLOW GAL/MIN (ambient flow, in gallons per minute); TDS (total dissolved solids); SULF (dissolved sulfate), $\mathrm{mg} / \mathrm{L}$ (milligrams per liter); cDCE (cis-1,2-DCE), tDCE (trans-1,2-DCE), $\mu \mathrm{g} / \mathrm{L}$ (micrograms per liter); SP COND $\mu \mathrm{S} / \mathrm{cm} 25^{\circ} \mathrm{C}$ (specific conductance, in microsiemens per centimeter at 25 degrees Celsius); and TMP DEG C (temperature, in degrees Celsius).]—Continued 
C

WS-14

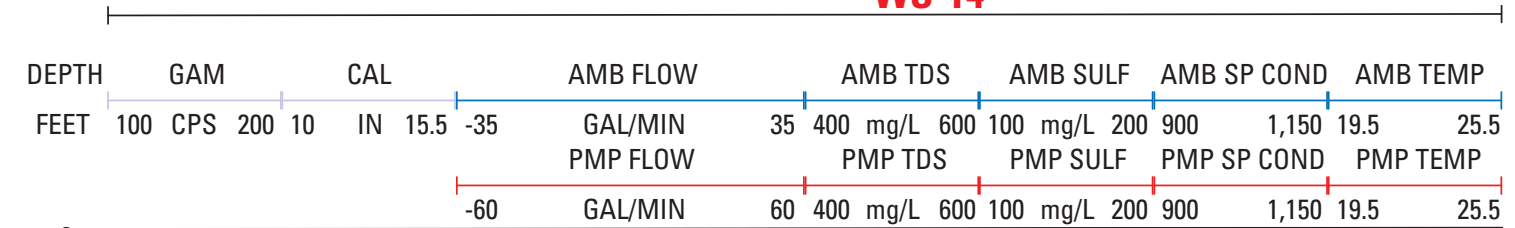

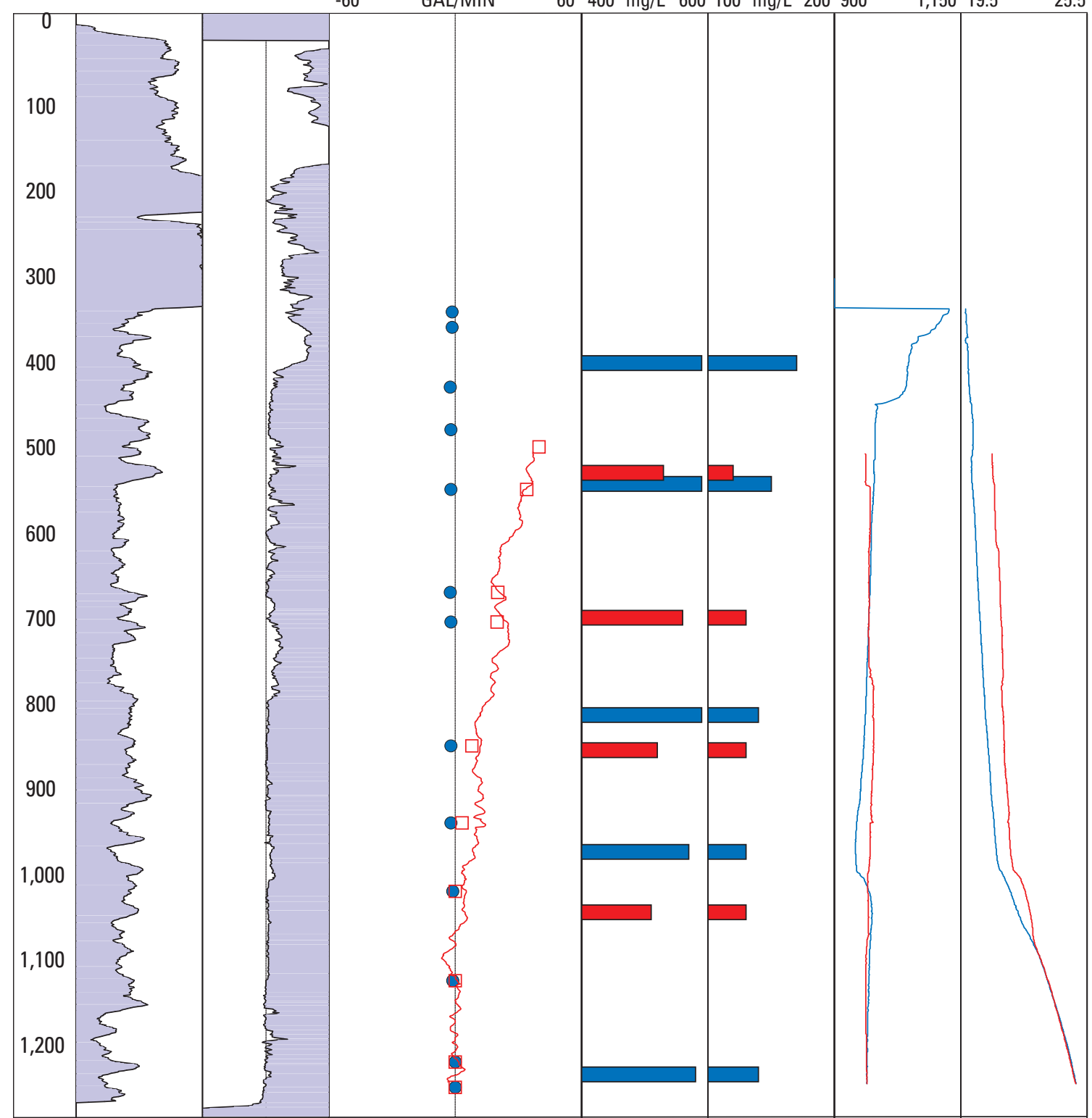

Figure 3. Geophysical logs and water-quality-sampling results for abandoned water-supply well (A)WS-12, (B) WS-13, and (C) WS-14, Santa Susana Field Laboratory, Ventura County, California. [DEPTH FEET (depth below top of casing, in feet); GAM CPS (gamma, in counts per second); CAL IN (caliper, in inches); AMB (ambient conditions); PMP (pumped conditions); FLOW GAL/MIN (ambient flow, in gallons per minute); TDS (total dissolved solids); SULF (dissolved sulfate), $\mathrm{mg} / \mathrm{L}$ (milligrams per liter); cDCE (cis-1,2-DCE), tDCE (trans-1,2-DCE), $\mu \mathrm{g} / \mathrm{L}$ (micrograms per liter); SP COND $\mu \mathrm{S} / \mathrm{cm} 25^{\circ} \mathrm{C}$ (specific conductance, in microsiemens per centimeter at 25 degrees Celsius); and TMP DEG C (temperature, in degrees Celsius).]—Continued 
downflow. The apparent increase in downflow may be related to the larger and more irregular borehole diameter in the interval above the $595-\mathrm{ft}$ zone than that below, or possibly the presence of crossflow in this interval. Another explanation is that the thermal conductivity of the rocks below the $595-\mathrm{ft}$ zone may be greater than those above, allowing for greater heat transfer and thereby increasing the temperature-log gradient (Peeter Pehme, University of Waterloo, written commun., 2008). Under the assumption that the 595 -ft zone is contributing additional downflow, this inflow had a higher specific conductance and total dissolved-solids concentration but lower concentrations of TCE and cis-1,2-DCE than the inflow above.

Outflow of the measurable downward flow was to a fracture zone at $770 \mathrm{ft}$. The temperature-log gradient indicates little vertical flow in the well below this depth. The water in the wellbore below $770 \mathrm{ft}$ had a relatively consistent specific conductance and total dissolved-solids concentration. TCE concentrations decreased with depth, and concentrations of cis-1,2-DCE and trans-1,2-DCE increased with depth. The water near the bottom of the well had concentrations of TCE, cis-1,2-DCE, and trans-1,2-DCE of 3, 43, and $6 \mu \mathrm{g} / \mathrm{L}$, respectively. The source and residence time of the water in the well below $770 \mathrm{ft}$ are unclear.

Under the pumped conditions, comparison of the ambient and pumped specific-conductance and temperature logs indicate little flow from below $770 \mathrm{ft}$. Under the pumped conditions, the $770-\mathrm{ft}$ zone contributes about $5 \mathrm{gal} / \mathrm{min}$. Most of the pumped flow, $50 \mathrm{gal} / \mathrm{min}$, was from the 595 -ft zone. The inflow from this zone had a specific conductance of more than $1,000 \mu \mathrm{S} / \mathrm{cm}$ at $25^{\circ} \mathrm{C}$ and a total dissolved-solids concentration of more than $650 \mathrm{mg} / \mathrm{L}$. Concentrations of TCE and cis-1,2DCE were less than 5 and $20 \mu \mathrm{g} / \mathrm{L}$, respectively, and trans-1,2DCE was not detected.

Well WS-13 is cased with 12-in.-diameter steel casing to a depth of $752 \mathrm{ft}$ (table 1). The casing is perforated below $22 \mathrm{ft}$, and the well is completed as a 12.5-in.-diameter open hole to a depth of $940 \mathrm{ft}$. The geophysical logs end at $915 \mathrm{ft}$ because of a blockage in the well. Altitude of the well is $1,658.62 \mathrm{ft}$ above NGVD 29. The well had an ambient water-level depth of $82.70 \mathrm{ft}$. The well was pumped at a rate of $99.5 \mathrm{gal} / \mathrm{min}$, which resulted in $2.96 \mathrm{ft}$ of drawdown after 150 minutes of pumping (fig. 2B). The specific capacity of the well was $34(\mathrm{gal} / \mathrm{min}) / \mathrm{ft}$.

Under the ambient conditions, downward flow due to inflow from fracture zones behind the perforated casing in well WS-13 progressively increased to a maximum of several gallons per minute at a depth of $560 \mathrm{ft}$ (fig. 3B). Below this depth, the downward flow decreased because there was outflow to fracture zones behind the perforated casing. The last of this downward flow may exit at a fracture zone behind the perforated casing at $708 \mathrm{ft}$. The downward flow had a relatively consistent specific conductance $(1,000 \mu \mathrm{S} / \mathrm{cm}$ at $25^{\circ} \mathrm{C}$ ) and total dissolved solids (580 to $590 \mathrm{mg} / \mathrm{L}$ ) and sulfate $(150 \mathrm{mg} / \mathrm{L})$. VOCs were not detected in this flow.
Ambient flow may be upwards from fracture zones below the logged depth of $915 \mathrm{ft}$ and from the fracture zone at $867 \mathrm{ft}$. This upward flow has a slightly higher specific conductance and total dissolved-solids concentration than the water from fracture zones behind the perforated casing. VOCs were not detected in this water. The upward flow appeared to exit at the fracture zone behind the perforated casing at $708 \mathrm{ft}$.

Under the pumped conditions, comparison of the ambient and pumped specific-conductance and temperature logs indicates upward flow from fractures zones below the logged depth of $915 \mathrm{ft}$ and from the fracture zone at $867 \mathrm{ft}$. Under the pumped conditions, the zones below $915 \mathrm{ft}$ contributed about $5 \mathrm{gal} / \mathrm{min}$ and the $867-\mathrm{ft}$ zone contributed about $20 \mathrm{gal} / \mathrm{min}$. The rest of the pumped flow, $75 \mathrm{gal} / \mathrm{min}$, was contributed by fracture zones behind the perforated casing, most of which were between 565 and $708 \mathrm{ft}$. The specific conductance of the pumped water from the 708 - $\mathrm{ft}$ zone appeared to be lower than the specific conductance of the water from the $867-\mathrm{ft}$ zone and zones below the logged depth. VOCs were not detected in the pumped flow.

Well WS-14 is cased with 16-in.-diameter steel casing to a depth of $40 \mathrm{ft}$ and is completed as a 12.75 -in.-diameter open hole to a depth of $1,272 \mathrm{ft}$ (table 1). Altitude of the well is $1,878.23 \mathrm{ft}$ above NGVD 29. The well had an ambient water-level depth of $336.82 \mathrm{ft}$. The well was pumped at a rate of $59 \mathrm{gal} / \mathrm{min}$, which resulted in $16.28 \mathrm{ft}$ of drawdown after 150 minutes (fig. 2C). The specific capacity of the well was $3.6(\mathrm{gal} / \mathrm{min}) / \mathrm{ft}$, which was the lowest specific capacity of the three wells.

Under ambient conditions, flow in well WS-14 was downward from fracture zones above and just below the water level to a fracture zone at $995 \mathrm{ft}$ at a rate near the lower measurement limit (fig. 3C). Inflow from fracture zones above the water level had a specific conductance of greater than $1,000 \mu \mathrm{S} / \mathrm{cm}$ at $25^{\circ} \mathrm{C}$, while inflow from fracture zones just below the water level had a specific conductance of less than $1,000 \mu \mathrm{S} / \mathrm{cm}$ at $25^{\circ} \mathrm{C}$. This apparent decrease in dissolved solids was reflected in the concentrations of dissolved sulfate and other ions but not in the total dissolved-solids concentrations. VOCs were not detected in the ambient flow

Under ambient conditions, the temperature gradient suggests little vertical flow in the well below the $995-\mathrm{ft}$ fracture zone. However, the temperature log under pumped conditions indicates some inflow from 1,070 ft. Fracture zones at 615,785 , and $995 \mathrm{ft}$ each contribute about onethird of the flow measured below the pump. The pumped -conditions specific-conductance log and total dissolved-solids concentrations indicate that the water from the 995 - $\mathrm{ft}$ fracture has more dissolved solids than water from zones just below the water level, but less than water from zones above the water level. VOCs were not detected in the pumped flow. 


\section{Summary}

Integrated analysis of flow, temperature, specificconductance logs, and depth-dependent water-quality samples were used for the preliminary delineation of flow zones and contaminants in three deep abandoned water-supply wells completed in a fractured-sandstone aquifer. In the well WS-12, which was $1,768 \mathrm{ft}$ deep and had the highest specific capacity of the three wells, flow zones were detected at 380 , 440,595 , and $770 \mathrm{ft}$. Under ambient conditions, measured flow was downward from the 380 - and $440-\mathrm{ft}$ zones to the 595- and 770-ft zones. Under pumped conditions, most of the flow was contributed by the 595 -ft zone. Flow from the $380-$ and 440-ft zones appeared to have lower specific conductance and higher TCE concentrations than flow from the 595-ft zone.

In well WS-13, which was reportedly $940 \mathrm{ft}$ deep but only logged to $915 \mathrm{ft}$ because of blockage, a flow zone was detected behind the perforated casing at $708 \mathrm{ft}$. Under ambient conditions, downward flow from zones behind the perforated casing and upward flow from zones at $867 \mathrm{ft}$ and below the logged depth appeared to exit at the $708-\mathrm{ft}$ zone. Most of the pumped flow was contributed from fracture zones behind the perforated casing between 565 and $708 \mathrm{ft}$. Zones at $867 \mathrm{ft}$ and below the logged depth also contributed pumped flow. The specific conductance of the pumped water from the $708-\mathrm{ft}$ zone appeared to be lower than the specific conductance of the water from zones at $867 \mathrm{ft}$ and below the logged depth. VOCs were not detected in the ambient and pumped flows.

In well WS-14, which was 1,272 ft deep and had the lowest specific capacity of the three wells, measured ambient flow was downward from zones above and just below the water level to a zone at $995 \mathrm{ft}$. Additional flow zones were detected under pumped conditions at 615,785 , and 1,070 ft. The specific conductance of flow from the zones near the water level was higher than that from deeper zones. VOCs were not detected in the ambient and pumped flows.

\section{References Cited}

Keys, W.S., 1990, Borehole geophysics applied to groundwater investigations: U.S. Geological Survey Techniques of Water-Resources Investigations, book 2, chap. E2, p. 150.

Paillet, F.L., 1998, Flow modeling and permeability estimation using borehole flow logs in heterogeneous fractured formations: Water Resources Research, v. 34, no. 5, p. 997-1010.

Paillet, F.L., 2004, Borehole flowmeter applications in irregular and large diameter boreholes: Journal of Applied Geophysics, v. 55, no. 1-2, p. 39-59.

Williams, J.H., and Conger, R.W., 1990, Preliminary delineation of contaminated water-bearing fractures intersected by open-hole bedrock wells: Ground Water Monitoring Review, v. 10, no. 4, p. 118-126.

Young, S.C., and Pearson, H.S., 1995, The electromagnetic borehole flowmeter-Description and applications: Ground Water Monitoring and Remediation Review, v. 15, no. 4, p. 138-146. 
For additional information write to: New York Water Science Center

U.S. Geological Survey

425 Jordan Road

Troy, NY 12180

Information requests:

(518) 285-5602

or visit our Web site at:

http://ny.water.usgs.gov 
